\section{Schizophrenic Birth Order: the Last but One Position}

RESULTs of birth order studies on schizophrenics from the United States, Canada and Britain suggest an increased incidence of patients born late in the family ${ }^{1-7}$.

A recent study, however, concludes that there is "an accumulation of evidence that the birth order distribution of schizophrenics varies with family size"-schizophrenics are born late in large families and early in small families ${ }^{8}$. Part of the evidence referred to is the sample of Solomon and Nuttall ${ }^{9}$ which included a large number of small families of high social class and which showed an increased incidence of early born patients. This bimodal result was explained by separate class-dependent factors operating in the different sizes of family. It is the purpose of this communication to test a single-factor explanation.

It is possible that the schizophrenic patient tends to occupy a certain position in relation to the end of the family rather than in relation to the beginning (a reverse ordinal position), so that the penultimate sib, for example, is born late in large families, while in two-sib families it is the first born. The hypothesis is that there is overrepresentation of the penultimate reverse ordinal position in schizophrenic samples.

By collecting data from the literature, a very large sample can be amassed. Five studies in the literature report samples of schizophrenics (total $N=3,482$ ) in such a way that distribution of the reverse ordinal positions can be calculated. The expocted distribution is calculated by the Greenwood-Yule method ${ }^{10}$. Over-representation is calculated as the difference between the observed and expected distribution as a percentage of the expected distribution. Table 1 shows that there is no continuous increase in over-representation towards the end of the family. There is a peak of over-representation at the last but one position-this is true consistently for all five samples individually.

There are two samples of non-schizophrenic psychiatric patients reported in the literature which allow a similar analysis-498 manic-depressives ${ }^{x}$ and 2,500 neurotics ${ }^{11}$.

In this non-schizophrenic sample there is no overrepresentation of the last but one position. 'Table 3 shows the fit between the schizophrenic sample and the nonschizophrenic sample (family size distribution corrected to that of the schizophrenic sample). 'The disparity between the samples is clearly greatest at the last but one position.

Table 1. DISTRIBUTION OF REVhRSE ORDINAL POSITIONS

\begin{tabular}{|c|c|c|c|}
\hline Reverse ordinal & Observed & Expected & $\begin{array}{c}\text { Percentage } \\
\text { uver-representation } \\
\text { Observed--Expected }\end{array}$ \\
\hline position & distribution & distribution & Expected \\
\hline $\begin{array}{l}\text { Last } \\
\text { Last but one } \\
\text { Last but two } \\
\text { Last but three } \\
\text { Rest } \\
N\end{array}$ & $\begin{array}{c}1,162 \cdot 5 \\
943 \\
534 \cdot 5 \\
347 \\
495 \\
\chi^{2}=121 .\end{array}$ & $\begin{array}{r}1,145 \\
860 \\
563 \\
339 \\
575 \\
52 \quad \text { d.f. }=4 \\
001\end{array}$ & $\begin{array}{l}+1.5 \\
+9.7 \\
-5.1 \\
+2.4\end{array}$ \\
\hline
\end{tabular}

$\begin{array}{cccc}\text { Table 1a. } & \text { SAMPLES CONTRIBUTING } & \text { TO TABLE } & \\ \text { Study } & N & \text { Country } & \text { Reference } \\ \text { Malzberg, 1940 } & 549 & \text { USA } & 1 \\ \text { Solomon and Nuttall, } 1967 & 291 & \text { USA } & 9 \\ \text { Barry and Barry, } 1967 & 1,019 & \text { USA } & 8 \\ \text { Gregory, 1959 } & 431 & \text { Canada } & 6 \\ \text { Granvile-Grossman, } 1966 & 1,192 & \text { England } & 7\end{array}$

Table 2. DISTRIBUTION OF REVERSF ORIMNAL POSITIONS OF NON-S(HIZ()-

$$
\begin{aligned}
& \begin{array}{l}
\text { Reverse ordinal } \\
\text { position }
\end{array} \\
& \text { Last } \\
& \text { Iast but one } \\
& \text { Last but two } \\
& \text { Iast bot three } \\
& \text { Rest } \\
& \text { N }
\end{aligned}
$$

\begin{tabular}{|c|c|c|}
\hline $\begin{array}{l}\text { Observed } \\
\text { distribution }\end{array}$ & $\begin{array}{c}\text { Expected } \\
\text { distribution }\end{array}$ & $\begin{array}{l}\text { Percentage over- } \\
\text { representation }\end{array}$ \\
\hline $\begin{array}{r}1,004 \\
463 \\
480 \\
319 \\
532\end{array}$ & $\begin{array}{l}927 \\
685 \\
474 \\
328 \\
584\end{array}$ & $\begin{array}{l}+8.3 \\
-3.2 \\
+1.2 \\
-2.7\end{array}$ \\
\hline$x^{2}=12 \cdot 78^{2}$ & d.f. $=4$ & \\
\hline
\end{tabular}
PHRENIC PATIENTS

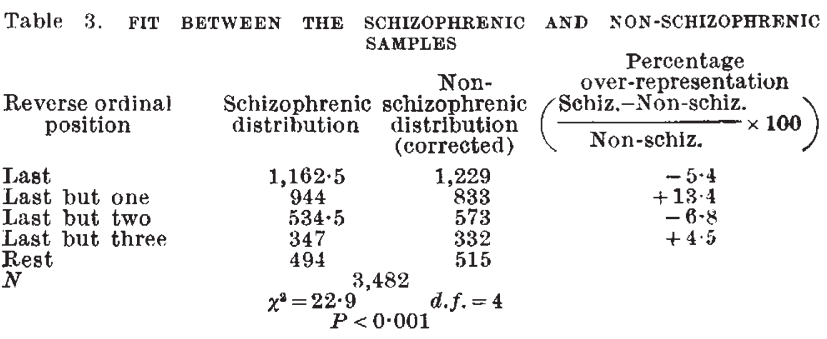

This new analysis of already published data clearly indicates that the presence of one younger sib is associated with schizophronia and can explain the anomalous results of Solomon and Nuttall without the introduction of social class factors.

One ordinal position is now identified with schizophrenia, so selection of these patients for further study will allow better understanding of what, if any, is the unique psychological position of the schizophrenic in the family.

Shenley Hospital,

\section{R. D. Hinshelwood}

St Albans,

Hertfordshire.

Received August 1, 1968.

1 Malzberg, B., Social and Biological Aspects of Mental Disease (Uticn, New York, 1940).

${ }^{2}$ Gregory, I., Brit. J. Prev. Soc. Med., 12, 42 (1958).

${ }^{3}$ Wabl, C. W. Amer. J. Psychiat., 113, 201 (1956).

"Schooler, C., Arch. Gen. Psychiat., 4, 91 (1961).

- Farina, A., Barry, H., and Garmezy, N., Arch. Gen. Psychiat., 9, 224 (1963).

'Gregory, I., Acta Genet., 9, 54 (1959).

? Granville-('rossman, K. L., Brit. J. Psychiat.,112, 1119 (1966).

8 Parry, H. and Barry, H., Arch. Gen. Psychiat., 17, 435 (1967).

- Solomon, L., and Nuttall, R., J. Nerv. Ment. Dis., 114, 37 (1967).

${ }^{10}$ Greenwood, M., and Yulc, G. U., J. Royal Stat. Soc., '7y, $179(1914)$

${ }^{\prime}$ Norton, A., Brit. J. Prev. Soc. Med., 6, 253 (1952).

\section{Evaluation of Teratogenicity of Lysergic Acid Diethylamide}

THE concern about the psychological and physiolngical effects of lysergic acid diethylamide (LSD) has naturally led to the desire for experimental models to study the spectra of effects suspected to be caused by LSD. Among the recent reports of its biological effects when pregnant animal models are used, one involving rats is negative ${ }^{1}$, another ${ }^{2}$ is ambiguous because although stunted and stillbirths were reported with LSD at 10 days post partum the offspring were unusually large, weighing $44.46 \mathrm{~g}$. Results with hamsters ${ }^{3}$ are equivocal because of the small incidence of malformations reported, and those for mice are positive ${ }^{4}$.

This report describes an attempt to demonstrate a teratogenic response to ISSD using pregnant mice and hamsters. In addition, secondary Syrian hamstor cultures were examined for growth alteration and for chromosomal aberrations in the presence of LSD. 'Delysid' (ISSD-25) was obtained from the US National Institutes of Health as a solution containing $0.1 \mathrm{mg} / \mathrm{ml}$. of LSD tartrate (Sandoz, lot No. 65002). Immediately before use, further dilutions were made with Dulbecco's salt solution which was also used for the control groups.

Syrian hamsters from the NIH breeding facilities, 9-II weeks old and weighing approximately $100 \mathrm{~g}$, wero used. This specios has responded to a wide variety of teratogens $^{5-7}$. They were injected intraperitoneally during the time of greatest differentiation with a single dose of $10 \mu \mathrm{g}$ (two animals), $100 \mu \mathrm{g}$ (four animals), $200 \mu \mathrm{g}$ (three animals) or $300 \mu \mathrm{g}$ (four animals) on days 6,7 or 8 ; in one case, 